\title{
Quality assurance of test results for the determination of Ingress Protection Code for Ex equipment enclosures
}

\author{
Dan Gabor $^{1 *}$, Niculina Vătavu ${ }^{1}$, Mihai Cătălin Popa ${ }^{1}$, Florin Păun ${ }^{1}$ and Adrian Marius \\ Jurca $^{1}$ \\ ${ }^{1}$ INCD INSEMEX, 32-34 G-ral Vasile Milea, Petroșani, Romania
}

\begin{abstract}
INSEMEX-OEC is a Conformity Assessment Body for certification activities in accordance with ATEX Directive 2014/34/EU, being accredited by RENAR and notified to Brussels (NB1809). INSEMEXGLI (Group of Testing Laboratories) is the main provider of laboratory testing services for the product certification body INSEMEX-OEC. The test laboratories meet the requirements of the standard SR EN ISO / IEC 17025. This standard requires laboratories to have a procedure in place to monitor the validity of the test results. This monitoring must be planned and, if possible, should include participation in inter-laboratory comparisons or proficiency testing programs. This paper presents some specific issues highlighted during the successful participation of INSEMEX-GLI in a round of inter-laboratory comparisons organized by the Physikalisch-Technische Bundesanstalt from Germany to determine International Protection Code (IP Code) for equipment enclosures.
\end{abstract}

\section{Introduction}

Maintaining the quality of laboratory tests can be achieved by participating in inter-laboratory comparisons. Inter-laboratory comparisons represent the organization, performance and evaluation of measurements or tests on the same or similar articles by two or more laboratories in accordance with pre-established conditions.

RENAR - Romanian Accreditation Association, which represents the National Accreditation Body of testing laboratories, in the publication „Policy on the use in accreditation of Proficiency Testing and Inter-laboratory comparisons" [1] underlines that ISO 17025 requires test laboratories to have a procedure in place to monitor the validity of test results and calibrations performed. This monitoring must be planned and may include, but is not limited to, participation in inter-laboratory comparisons or proficiency testing programs.

The data obtained from the monitoring process must be recorded in such a way that trends can be identified, they must be analysed and when they are found to be outside the pre-set criteria, actions must be taken to correct the situation and prevent the reporting of incorrect results.

* Corresponding author: dan.gabor@insemex.ro 
Participation within a Proficiency Testing Scheme is essential for the compliance with the requirements of ISO/IEC 17025 and IECEx laboratory assessment requirements regarding the need of the Ex-laboratories to perform inter-laboratory comparisons. In addition, the results of Proficiency Testing programs will contribute considerably to the development of the "Peer concept" within the global community of Ex laboratories. The results of the Proficiency Testing Scheme will also be of direct use for all participants, among others for:

- demonstrating the competence of customers, regulators and end-users,

- identifying and avoiding problems in and between Ex laboratories and initiating improvement measures,

- establishing the effectiveness and comparability of the test and measurement methods applied,

- support for IEC / TC 31 by providing results and findings to the respective maintenance teams / working groups,

- ensuring additional trust for the client,

- avoiding distortions of competition between manufacturers as customers of testing laboratories,

- promotion of the "fair play" culture [2].

INSEMEX OEC is constituted within INCD INSEMEX Petroşani as a product certification body and operates as a well-defined and independent entity in the organizational structure.

INSEMEX-OEC is a Conformity Assessment Body for product certification activities in accordance with ATEX Directive 2014/34 / EU, transposed in Government Decision 245/2016, being accredited by RENAR - Romanian Accreditation Association (Certificate of accreditation ON 046) and notified in Brussels with no. NB 1809.

RENAR accreditation was based on the body's assessment of compliance with the requirements SR EN ISO / CEI 17065: 2013. One of the requirements refers to the evaluation based on the results of the tests performed in competent laboratories.

The test laboratory group INSEMEX GLI is the main supplier of laboratory testing services for the INSEMEX OEC product certification body, being accredited by RENAR (accreditation certificate no. LI 347) on its competence to perform tests based on SR ISO / IEC 17025: 2018 requirements and accreditation criteria established by the Romanian Accreditation Association - RENAR.

In recent years, INCD INSEMEX has invested heavily in the development of the material base. The results are seen in the quality of the tests performed in the laboratories; quality demonstrated by the inter-laboratory tests.

One of the requirements imposed regarding equipment for explosive atmospheres refers to providing a certain degree of protection against the intrusion of dust and water into the enclosure - IP Code. Thus, in order to evaluate the conformity of the equipment with the requirements of the applicable standards in the explosion protection field, respectively the testing of the equipment for determining the normal degree of protection within INSEMEX GLI Testing Laboratories Group, state-of-the-art equipment / test stand was purchased and developed and implemented testing procedures in the quality system.

\section{IP Code and the importance of determining the degree of protection provided by enclosures for Ex equipment}

The IP Code, or International Protection Code, sometimes referred to as Ingress Protection Code, according to standard SR EN 60529 is defined as a coding system to indicate the degrees of protection provided by an enclosure against access to hazardous parts, ingress of solid foreign objects, ingress of water and to give additional information in connection 
with such protection. Degree of protection refers to the extent of protection provided by an enclosure against access to hazardous parts, against ingress of solid foreign objects, and/or against ingress of water, and verified by standardized test methods.

Standardized test methods are detailed in SR EN 60529 and the purpose of the standard is to give:

- Definitions for degrees of protection provided by enclosures of electrical equipment as regards:

- protection of persons against access to hazardous parts inside the enclosure;

- protection of the equipment inside the enclosure against ingress of solid foreign objects;

- protection of the equipment inside the enclosure against harmful effects due to the ingress of water.

- Designations for these degrees of protection.

- Requirements for each designation.

- Tests to verify that the enclosure meets the requirements of the specific standard regarding IP Code [3].

The degree of protection provided by an enclosure is indicated by the IP Code in the following way:

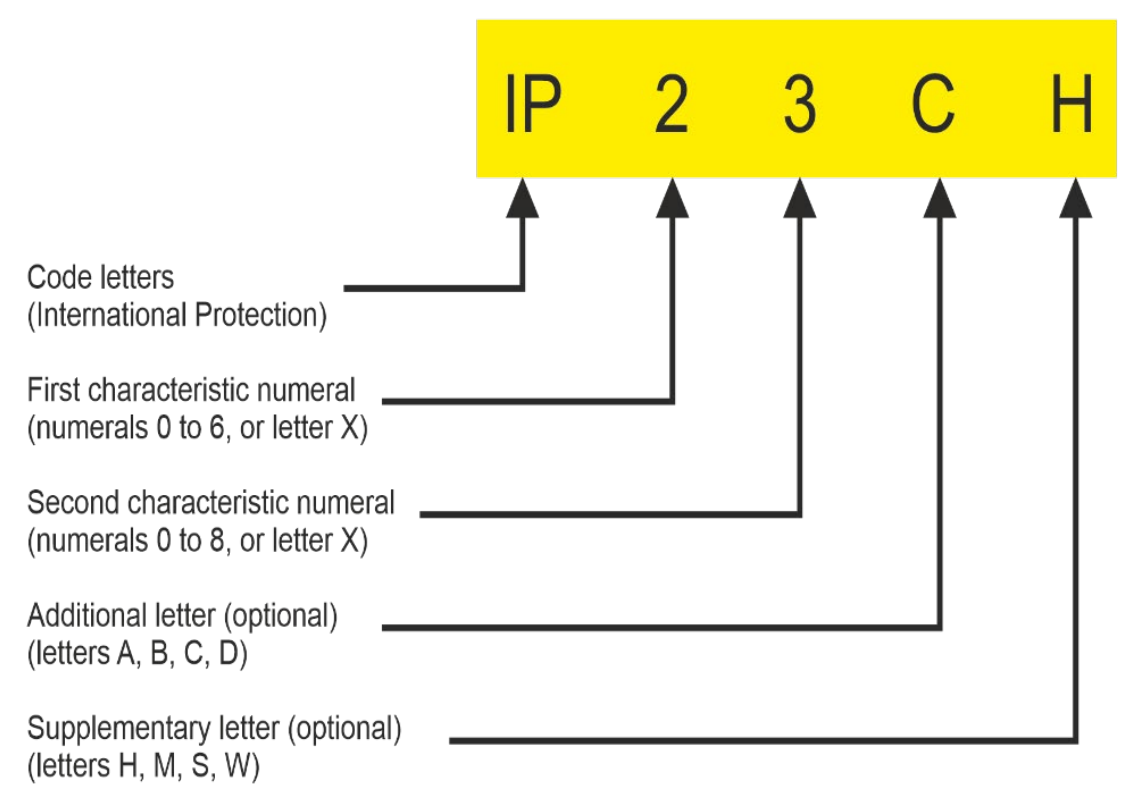

Fig. 1. Arrangement of the IP Code.

Where a characteristic numeral is not required to be specified, it shall be replaced by the letter "X" ("XX" if both numerals are omitted). Additional letters and/or supplementary letters may be omitted without replacement. Where more than one supplementary letter is used, the alphabetic sequence shall apply. If an enclosure provides different degrees of protection for different intended mounting arrangements, the relevant degrees of protection shall be indicated by the manufacturer in the instructions related to the respective mounting arrangements. 
Table 1. Elements of the IP Code and their meanings [3].

\begin{tabular}{|c|c|c|c|}
\hline Element & $\begin{array}{l}\text { Numerals } \\
\text { or letters }\end{array}$ & $\begin{array}{c}\text { Meaning for the protection } \\
\text { of equipment }\end{array}$ & $\begin{array}{l}\text { Meaning for } \\
\text { the protection } \\
\text { of persons }\end{array}$ \\
\hline Code letters & IP & - & - \\
\hline $\begin{array}{c}\text { First } \\
\text { characteristic } \\
\text { numeral }\end{array}$ & $\begin{array}{l}0 \\
1 \\
2 \\
3 \\
4 \\
5 \\
6\end{array}$ & $\begin{array}{l}\text { Against ingress of solid } \\
\text { foreign objects } \\
\text { (non-protected) } \\
>50 \mathrm{~mm} \text { diameter } \\
>12,5 \mathrm{~mm} \text { diameter } \\
>2,5 \mathrm{~mm} \text { diameter } \\
>1,0 \mathrm{~mm} \text { diameter } \\
\text { dust-protected } \\
\text { dust-tight }\end{array}$ & $\begin{array}{l}\text { Against access } \\
\text { to hazardous } \\
\text { parts with } \\
\text { (non- } \\
\text { protected) } \\
\text { back of hand } \\
\text { finger } \\
\text { tool } \\
\text { wire } \\
\text { wire } \\
\text { wire } \\
\end{array}$ \\
\hline $\begin{array}{c}\text { Second } \\
\text { characteristic } \\
\text { numeral }\end{array}$ & $\begin{array}{l}0 \\
1 \\
2 \\
3 \\
4 \\
5 \\
6 \\
7 \\
8 \\
\end{array}$ & $\begin{array}{l}\text { Against ingress of water } \\
\text { with harmful effects } \\
\text { (non-protected) } \\
\text { vertically dripping } \\
\text { dripping }\left(15^{\circ} \text { tilted) }\right. \\
\text { spraying } \\
\text { splashing } \\
\text { jetting } \\
\text { powerful jetting } \\
\text { temporary immersion } \\
\text { continuous immersion }\end{array}$ & - \\
\hline $\begin{array}{c}\text { Additional } \\
\text { letter (optional) }\end{array}$ & $\begin{array}{l}\text { A } \\
\text { B } \\
\text { C } \\
\text { D }\end{array}$ & - & $\begin{array}{l}\text { Against access } \\
\text { to hazardous } \\
\text { parts with: } \\
\text { back of hand } \\
\text { finger } \\
\text { tool } \\
\text { wire }\end{array}$ \\
\hline $\begin{array}{l}\text { Supplementary } \\
\text { letter (optional) }\end{array}$ & $\begin{array}{c}\mathrm{H} \\
\mathrm{M} \\
\mathrm{S} \\
\mathrm{W}\end{array}$ & $\begin{array}{l}\text { Supplementary information } \\
\text { specific to: } \\
\text { High voltage apparatus } \\
\text { Motion during water test } \\
\text { Stationary during water test } \\
\text { Weather conditions }\end{array}$ & - \\
\hline
\end{tabular}

\subsection{Tests to determine degree of protection against solid foreign objects indicated by the first characteristic numeral}

Table 2 gives brief descriptions and the definitions for the degrees of protection against the penetration of solid foreign objects including dust. 
Table 2. Degrees of protection against solid foreign objects indicated [3].

\begin{tabular}{|c|c|c|}
\hline \multirow{2}{*}{$\begin{array}{c}\text { First } \\
\text { characteristic } \\
\text { numeral }\end{array}$} & \multicolumn{2}{|c|}{ Degrees of protection } \\
\hline & Brief description & Definition \\
\hline 0 & Non-protected & - \\
\hline 1 & $\begin{array}{l}\text { Protected against solid foreign } \\
\text { objects of } 50 \mathrm{~mm} \varnothing \text { and greater }\end{array}$ & $\begin{array}{c}\text { The object probe, sphere of } 50 \mathrm{~mm} \varnothing, \\
\text { shall not fully penetrate }\end{array}$ \\
\hline 2 & $\begin{array}{l}\text { Protected against solid foreign } \\
\text { objects of } 12,5 \mathrm{~mm} \varnothing \text { and greater }\end{array}$ & $\begin{array}{l}\text { The object probe, sphere of } 12,5 \mathrm{~mm} \varnothing \text {, } \\
\text { shall not fully penetrate }{ }^{1)}\end{array}$ \\
\hline 3 & $\begin{array}{l}\text { Protected against solid foreign } \\
\text { objects of } 2,5 \mathrm{~mm} \varnothing \text { and greater }\end{array}$ & $\begin{array}{l}\text { The object probe, sphere of } 2,5 \mathrm{~mm} \mathrm{Ø,} \\
\text { shall not penetrate at all }{ }^{1)}\end{array}$ \\
\hline 4 & $\begin{array}{l}\text { Protected against solid foreign } \\
\text { objects of } 1,0 \mathrm{~mm} \emptyset \text { and greater }\end{array}$ & $\begin{array}{l}\text { The object probe of } 1,0 \mathrm{~mm} \emptyset \text {, shall not } \\
\text { penetrate at all }{ }^{1)}\end{array}$ \\
\hline 5 & Dust-protected & $\begin{array}{l}\text { Ingress of dust is not totally prevented, } \\
\text { but dust shall not penetrate in a quantity } \\
\text { to interfere with satisfactory operation of } \\
\text { the apparatus or to impair safety }\end{array}$ \\
\hline 6 & Dust-tight & No ingress of dust \\
\hline
\end{tabular}

\subsection{Tests to determine the degree of protection against ingress of water indicated by the second characteristic numeral}

Table 3 gives brief descriptions and definitions of the degree protection represented by the second characteristic numeral.

Table 3. Degrees of protection against water indicated by the second characteristic numeral [3].

\begin{tabular}{|c|c|c|}
\hline \multirow{2}{*}{$\begin{array}{l}\text { Second } \\
\text { characteri } \\
\text { stic } \\
\text { numeral }\end{array}$} & \multicolumn{2}{|c|}{ Degree of protection } \\
\hline & Brief description & Definition \\
\hline 0 & Non-protected & - \\
\hline 1 & $\begin{array}{l}\text { Protected against vertically } \\
\text { falling water drops }\end{array}$ & $\begin{array}{l}\text { Vertically falling drops shall have no } \\
\text { harmful effects }\end{array}$ \\
\hline 2 & $\begin{array}{l}\text { Protected against vertically } \\
\text { falling water drops when } \\
\text { enclosure tilted up to } 15^{\circ}\end{array}$ & $\begin{array}{l}\text { Vertically falling drops shall have no } \\
\text { harmful effects when the enclosure is } \\
\text { tilted at any angle up to } 15 \text { " on either side } \\
\text { of the vertical }\end{array}$ \\
\hline 3 & $\begin{array}{l}\text { Protected against spraying } \\
\text { water }\end{array}$ & $\begin{array}{l}\text { Water sprayed at an angle up to } 60^{\circ} \text { on } \\
\text { either side of the vertical shall have no } \\
\text { harmful effects }\end{array}$ \\
\hline 4 & $\begin{array}{l}\text { Protected against splashing } \\
\text { water }\end{array}$ & $\begin{array}{l}\text { Water splashed against the enclosure from } \\
\text { any direction shall have no harmful } \\
\text { effects }\end{array}$ \\
\hline 5 & Protected against water jets & $\begin{array}{l}\text { Water projected in jets against the } \\
\text { enclosure from any direction shall have } \\
\text { no harmful effects }\end{array}$ \\
\hline
\end{tabular}




\begin{tabular}{|c|l|l|}
\hline $\begin{array}{c}\text { Second } \\
\text { characteri } \\
\text { stic } \\
\text { numeral }\end{array}$ & \multicolumn{2}{|c|}{ Degree of protection } \\
\cline { 2 - 3 } & \multicolumn{1}{|c|}{ Brief description } & \multicolumn{1}{c|}{ Definition } \\
\hline 6 & $\begin{array}{l}\text { Protected against powerful } \\
\text { water jets }\end{array}$ & $\begin{array}{l}\text { Water projected in powerful jets against } \\
\text { the enclosure from any direction shall } \\
\text { have no harmful effects }\end{array}$ \\
\hline 7 & $\begin{array}{l}\text { Protected against the effects of } \\
\text { temporary immersion in water }\end{array}$ & $\begin{array}{l}\text { Ingress of water in quantities causing } \\
\text { harmful effects shall not be possible when } \\
\text { the enclosure is temporarily immersed in } \\
\text { water under standardized conditions of } \\
\text { pressure and time }\end{array}$ \\
\hline 8 & $\begin{array}{l}\text { Protected against the effects of } \\
\text { continuous immersion in water }\end{array}$ & $\begin{array}{l}\text { harmful effects shall not be possible when } \\
\text { the enclosure is continuously immersed in } \\
\text { water under conditions which shall be } \\
\text { agreed between manufacturer and user but } \\
\text { which are more severe than for numeral } 7\end{array}$ \\
\hline
\end{tabular}

Enclosures used for Ex equipment must comply with standard SR EN IEC 60079-0:2018. This part of IEC 60079 specifies the general requirements for the construction, testing and marking of Ex Equipment and Ex Components intended for use in explosive atmospheres. The standard atmospheric conditions (relating to the explosion characteristics of the atmosphere) under which it may be assumed that Ex Equipment can be operated are:

- temperature: $-20{ }^{\circ} \mathrm{C}$ to $+60{ }^{\circ} \mathrm{C}$;

- pressure: 0,8 bar to 1,1 bar; and

- air with normal oxygen content (21\% v/v) [4].

In this standard we also find the tests that must be performed on the equipment intend for use in potentially explosive atmospheres. At point 26.4 of this standard appears the requirement "Test of enclosures". Furthermore, this standard specifies the test procedures for the type of protection that must be in accordance with the IEC 60529.

\section{The proficiency testing scheme. Organizer of the proficiency testing scheme.}

Proficiency Testing Scheme - Proficiency testing designed and operated in one or more rounds for a specified area of testing, measurement, calibration or inspection.

Proficiency Testing - Evaluation of the performance of the participant against preestablished criteria by means of inter-laboratory comparisons.

Inter-laboratory comparisons - Organization, execution and evaluation of measurements or tests on the same or similar items by two or more laboratories in accordance with predetermined conditions.

The organizer of the proficiency testing scheme was Physikalisch-Technische Bundesanstalt (PTB), the National Institute of Metrology in the Federal Republic of Germany. Physikalisch-Technische Bundesanstalt (PTB) is a scientific and technical higher federal authority within the portfolio of the Federal Ministry for Economic Affairs and Energy.

PTB named the program: "Program Tests of Enclosures - Test Round 2019" and the results were presented online in PTB Ex PT Workshops 2020/2021. The number of registered laboratories was 92.

IP tests were performed for Water Protection (IP X4) and Dust Protection (IP 5X).

Normative Basis for this program was ISO/IEC 17043 - Conformity assessment - 
General requirements for proficiency testing and ISO 13528 - Statistical methods for use in proficiency testing by inter-laboratory comparisons.

\section{Tests of enclosures in practice}

Normative background for tests: IEC 60079-0 \& IEC 60529.

Characteristic of interest: compliance with the degree of protection (IP):

- Protection against water (IP X4),

- Protection against dust (IP 5X).

Tests were performed on 12 samples with the following characteristics (Fig.2.):

\begin{tabular}{|ll|}
\hline Technical Data & \\
Dimension: & $(170 \times 170 \times 91) \mathrm{mm}(\mathrm{W} \times \mathrm{H} \times \mathrm{D})$ \\
Weight: & $0.86 \mathrm{~kg}$ \\
Service temperature (Ts): & $-20 \ldots+100{ }^{\circ} \mathrm{C}$ \\
Material: & Polyester resin, glass-fibre-reinforced, dark grey, similar to RAL \\
& 7024 \\
Cover lock: & With captive M6 stainless steel combo head screws according to \\
& the specification of the terminal block manufactures \\
Torque for screws: & $4.5 \mathrm{Nm}$ \\
Enclosure volume: & $1.94 \mathrm{I}$ \\
Type of installation: & Wall mounting \\
\hline
\end{tabular}

Fig. 2. Technical data of the samples.

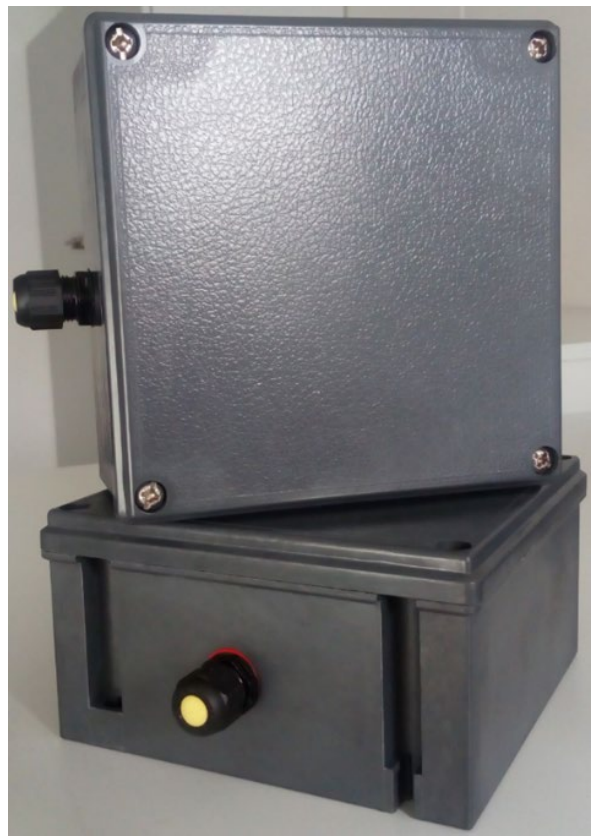

Fig. 3. Sample photo (what the enclosure looks like). 


\subsection{Protection against water (IP X4 test)}

For performing the IP X4 test, the steps from the flow chart shown in Fig. 4. were followed.

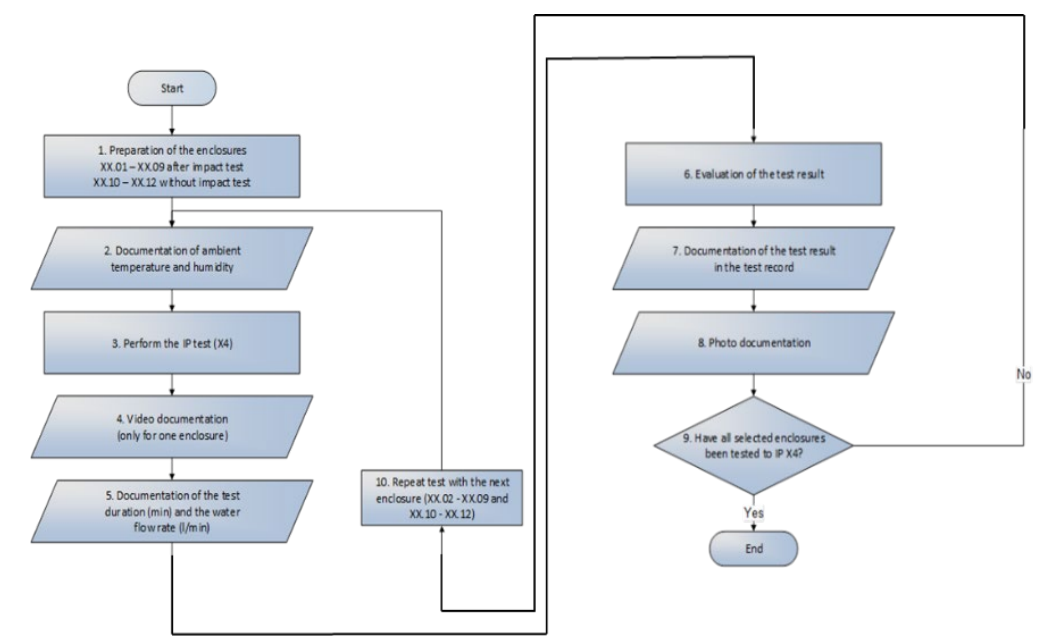

Fig. 4. IP X4 flowchart [9].

The equipment used for testing by INSEMEX GLI complies with the specifications of the standard and is identical to that in the drawing in fig. 5.

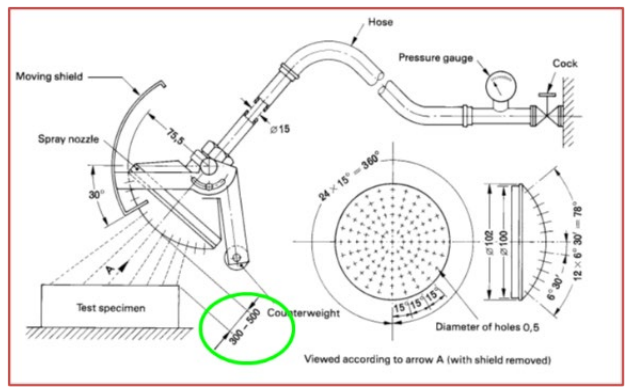

Fig. 5. Test equipment used by INSEMEX-GLI for IP X4 test.

Mounting, assembling and positioning of the samples was done on a vertically perforated panel (fig. 6.). The spray was applied from the front, from the top, from the bottom and from the sides (from all possible directions).

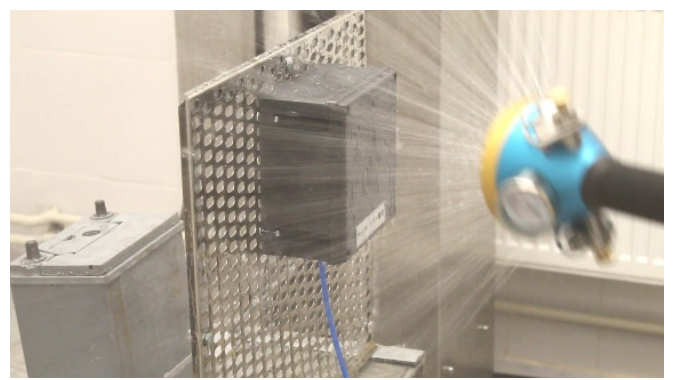

Fig. 6. Image during the IP X4 test. The sample positioned vertically, in the normal working position of the equipment. 


\subsection{Protection against dust (IP 5X test)}

For performing the IP 5X test, the steps from the flow chart shown in Fig. 7. were followed.

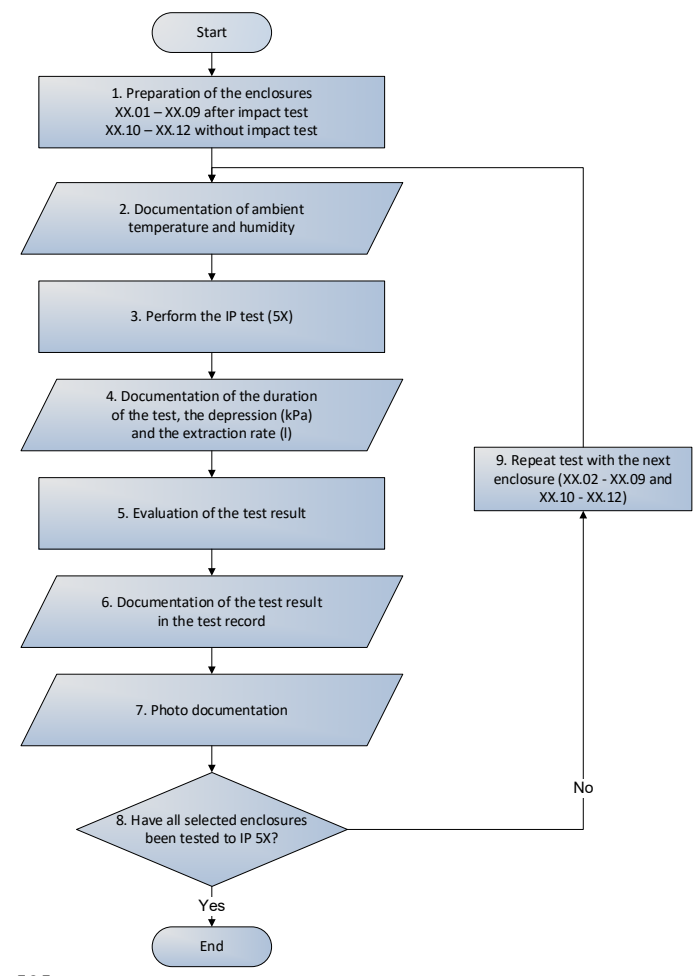

Fig. 7. IP $5 \mathrm{X}$ flowchart [9].

The equipment used for testing by INSEMEX GLI complies with the specifications of the standard and is shown in photo (Fig. 8.). The equipment was a dust chamber with a volume of $0.6 \mathrm{~m}^{3}$.

The object of the test is to draw into the enclosure, by means of depression, a volume of air 80 times the volume of the sample enclosure tested without exceeding the extraction rate of 60 volumes per hour. Under no circumstance shall the depression exceed $2 \mathrm{kPa}$ ( 20 mbar) on the $\mathrm{U}$ tube.

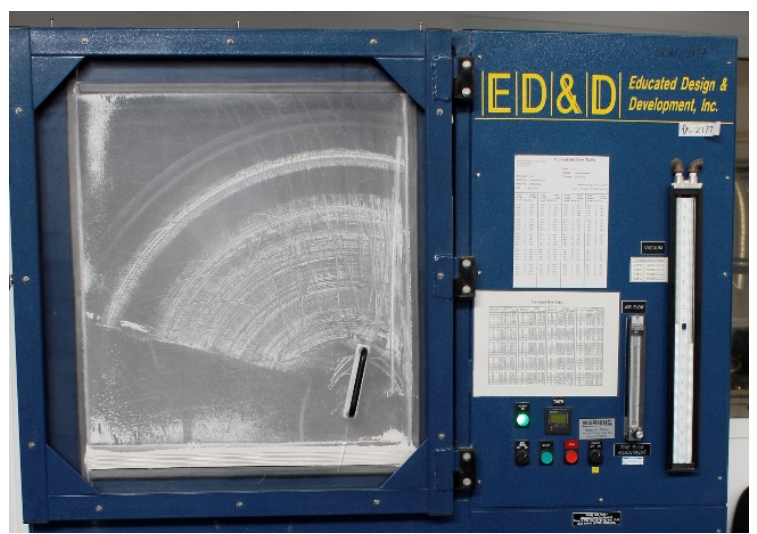

Fig. 8. Test equipment used by INSEMEX-GLI for IP $5 \mathrm{X}$ test, $0.6 \mathrm{~m}^{3}$ Dust Chamber. 
What to consider when performing the IP5X test:

- Consideration of the IECEx DS 2012/003 "Dust Testing for IP5X and IP6X"

- The standard requirements shall be met, especially concerning the following:

- atmospheric conditions (clumping of talcum powder caused by high humidity),

- number of uses of talcum powder.

-When testing several enclosures simultaneously, care should be taken to ensure that the dust chamber system used is suitable to meet the depression and extraction rate requirements for each individual enclosure,

- After performing the test, when opening the enclosure care should be taken to ensure that no dust from outside enters the enclosure and thus influences the assessment of the acceptance criterion.

\section{Results of inter-laboratory tests}

The statistical model has been developed and documented in line with the requirements of the standard ISO 17043. The following statistical parameters and graphical presentations are used for statistical analysis and description of the participants' results. For a description of statistical parameters, the standards ISO 13528 and ISO 17043 were used.

The descriptive statistics for this program cover only the location parameters. The expected value corresponds directly to the test result in terms of passed/failed evaluations.

The difference is the estimate of the absolute differences between the assigned value and the participant's result.

The results of the inter-laboratory tests for IPX4 are presented in figure 9 and for IP5X in figure 10. The results of the laboratory within INSEMEX GLI are highlighted in yellow (LC0026).

After evaluating the results there are 14 laboratories with warning signal and 3 laboratories with action signal (these laboratories are outside of limits). The most important thing is that INSEMEX GLI laboratory is not part of these laboratories.

Comparing the results of the laboratory within INCD Insemex with the results of the other 84 laboratories from all over the world, we find that our results are very good.

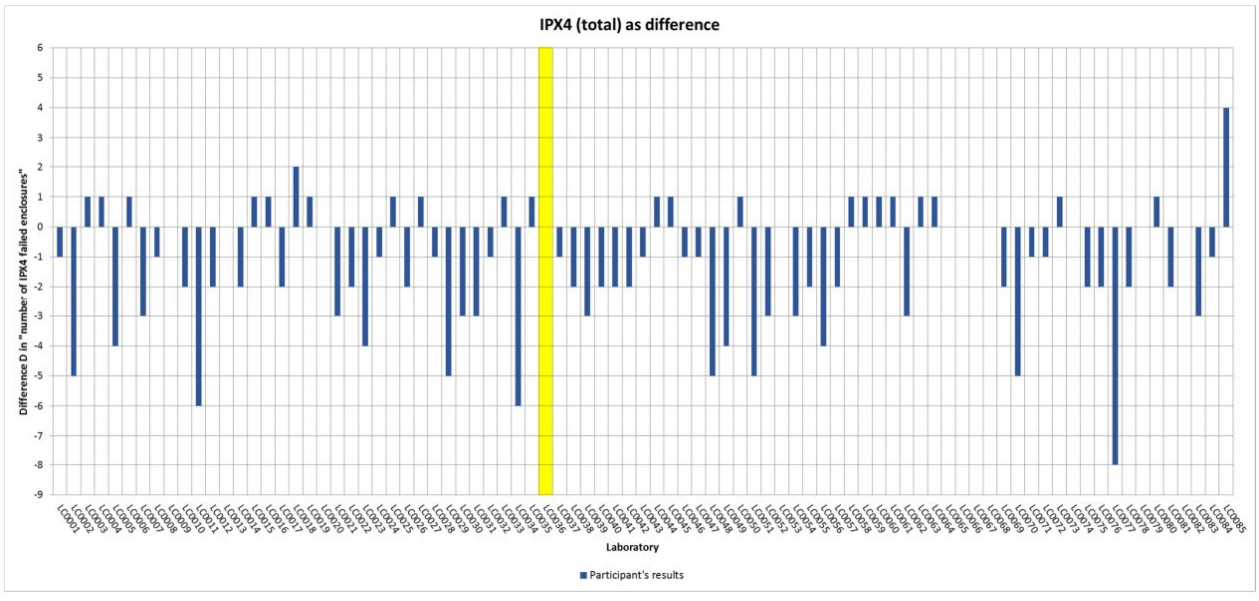

Fig. 9. Results (as difference) for IP X4. INSEMEX GLI laboratory at position LC0026 [10]. 


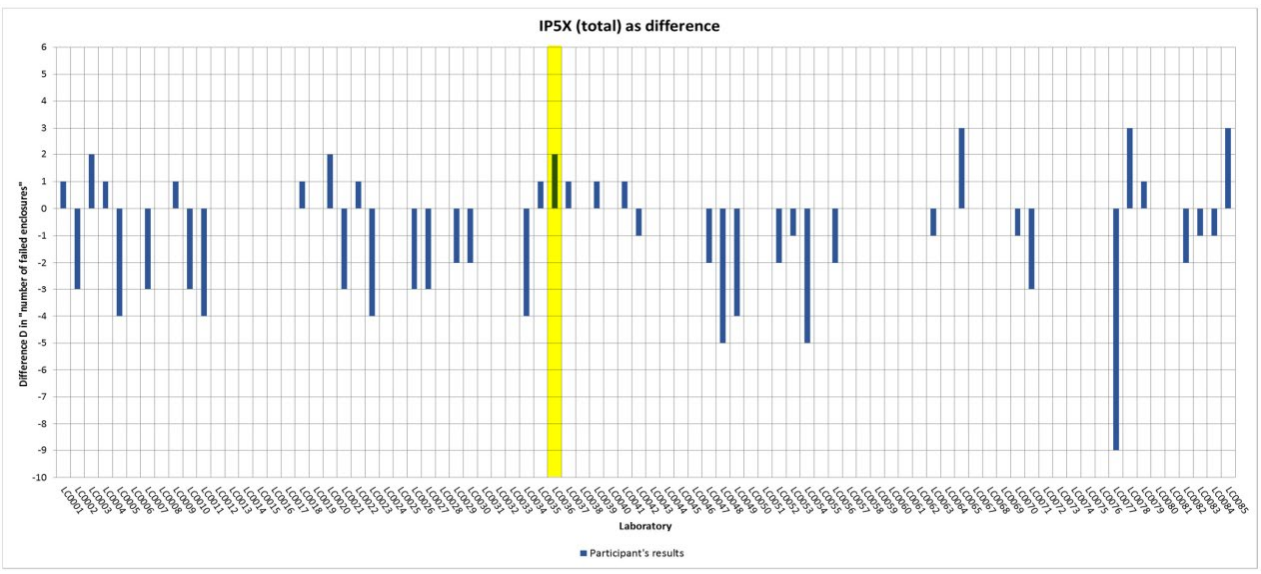

Fig. 10. Results (as difference) for IP 5X. INSEMEX GLI laboratory at position LC0026 [10].

\section{Conclusion}

In order to ensure a good quality of the tests, in accordance with the European and international requirements, investments must be made to ensure the material and human base.

Without high performance testing equipment and without trained staff, top results cannot be obtained.

INCD INSEMEX has invested a lot in the previous years in the development of the infrastructure and in the training of the personnel and the results started to appear immediately.

The equipment necessary for the laboratory tests was purchased partly within some research projects and partly from own sources.

The very good results of the inter-laboratory tests led to the validation of the quality of the tests performed within INSEMEX through the GLI laboratories, international level laboratories.

\section{References}

1. RENAR - Asociația de Acreditare din România, Politica privind utilizarea în acreditare a incercărilor de competență și a comparărilor interlaboratoare, Cod: P-04 (2019)

2. PTB Working Group 3.54, Roll-out for Test Round 2021 (2021)

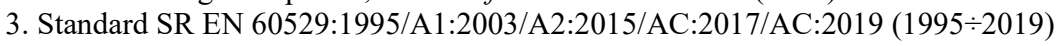

4. M. Thedens, PTB Workshops presentation - Tests of Enclosures - Test Round 2019 (2020)

5. Standard SR EN IEC 60079-0 (2018)

6. D. Markus, PTB Workshops presentation - Tests of Enclosures - Test Round 2019 (2020)

7. L. Ostermann, PTB Workshops presentation - Tests of Enclosures - Test Round 2019 (2020)

8. INCD INSEMEX, Product Conformity Assessment Body, https://insemex.ro/serviciu-de-certificareechipamente-ex/

9. T. Krause, PTB Workshops presentation - Tests of Enclosures - Test Round 2019 (2020)

10. L. Ostermann, Interim Report for the program "Tests of Enclosures - Test Round 2019" of the

PTB Ex Proficiency Testing Scheme (2020)

11. Standard SR EN ISO / IEC 17025 (2018)

12. ATEX Directive 2014/34/EU (2014)

13. IECEx DS 2012/003, Collection of IECEx / ExTAG decision (2012)

14. Standard SR EN ISO/CEI 17065 (2013)

15. Standard SR EN ISO/CEI 17043 (2010)

16. Standard SR EN ISO/IEC 17011 (2018) 